\title{
Impact of sowing time, hybrid and environmental conditions on the contamination of maize by emerging mycotoxins and fungal metabolites
}

\author{
Massimo Blandino, ${ }^{1}$ Valentina Scarpino, ${ }^{1}$ Debora Giordano, ${ }^{1}$ Michael Sulyok, ${ }^{2}$ Rudolf Krska, ${ }^{2}$ \\ Francesca Vanara, ${ }^{1}$ Amedeo Reyneri ${ }^{1}$ \\ ${ }^{1}$ Department of Agricultural, Forestry and Food Sciences, University of Turin, Grugliasco (TO), Italy; \\ ${ }^{2}$ Center for Analytical Chemistry, Department of Agrobiotechnology, University of Natural Resources and \\ Life Sciences, Vienna, Austria
}

\begin{abstract}
Mycotoxins and other fungal metabolites represent the most insidious safety risks to cereal food and the feed chain. Optimising agronomic practices is one of the main strategies adopted to minimise the contents of these undesirable substances in grain-based commodities. The aim of this study was to investigate the effect of the combination of sowing times and hybrids on the occurrence of emerging mycotoxins and fungal metabolites in maize. Field experiments were carried out in 2 sowing times (early $v s$ late) and 3 maize hybrids were compared in the 2014 and 2015 growing seasons. Overall, 37 fungal metabolites produced by Fusarium and Alternaria species were detected. Apart from fumonisins type $\mathrm{B}$ (FBs), other metabolites produced by Fusarium verticillioides and $F$. proliferatum, such as fumonisins type A, fusaric acid, bikaverin and fusaproliferin, were also detected in all of the samples. Fusarin C was found in $61 \%$ of the samples. Deoxynivalenol
\end{abstract}

Correspondence: Massimo Blandino, Department of Agricultural, Forestry and Food Sciences, University of Turin, Largo P. Braccini 2, I-10095 Grugliasco (TO), Italy.

Tel: +39-011-6708895; fax +39-011-6708798.

E-mail: massimo.blandino@unito.it

Acknowledgements: the authors would like to thank Paolo Barbera, Andrea Borio, Matteo Calcagno, Davide Conforti, Stefania Stura and Giulio Testa for their precious help and cooperation in the laboratory and field work.

Funding: the research has been conducted thanks to the financial support of the Italian Ministry of Agricultural, Food and Forestry Policies (MIPAAF), as a part of the Rete qualità cereali plus - Mais (RQC Mais) project (Coordinator Dr. Carlotta Balconi, CREA - MAC).

Key words: Alternaria; Ear rot; Field prevention; Fusarium; Maize.

Received for publication: 26 January 2017.

Revision received: 20 March 2017.

Accepted for publication: 21 March 2017.

(C) Copyright M. Blandino et al., 2017

Licensee PAGEPress, Italy

Italian Journal of Agronomy 2017; 12:928

doi:10.4081/ija.2017.928

This article is distributed under the terms of the Creative Commons Attribution Noncommercial License (by-nc 4.0) which permits any noncommercial use, distribution, and reproduction in any medium, provided the original author(s) and source are credited.
(DON), deoxynivalenol-3-glucoside, culmorin and zearalenone, all of which are produced prevalently by Fusarium graminearum and F. culmorum, were found in all the samples. Their contents were clearly affected by the meteorological trend: the highest contamination was detected in the 2014 growing season, which was characterised by abundant rainfall and lower temperatures from flowering to maize ripening. Among the mycotoxins produced by other Fusarium species, aurofusarin was found to clearly be associated with DON, while moniliformin and beauvericin followed the same behaviour as the FBs.

A late sowing time significantly increased the FBs and fumonisin-associated mycotoxins in both growing seasons. The increase in contamination with the delay of sowing was more pronounced in the 2015 growing season, as the environmental conditions were less favourable to the infection of other Fusarium species. The effect of sowing time on DON and DON-associated mycotoxins produced conflicting results for the two growing seasons, because contamination by these metabolites depends more on the conditions that occur during maize flowering than those that occur during ripening. A clearer hybrid susceptibility was observed for these compounds. Other metabolites, such as enniatins, equisetin, T-2 and HT-2 toxins and Alternaria toxins, were always found in traces. The occurrence of these metabolites seems to be influenced less by the considered agronomic practices.

The results, obtained under naturally-infected field conditions, underline the key role that the sowing date and hybrid susceptibility play in influencing, in a variable way, the contamination of mycotoxins produced by different Fusarium species in maize subjected to different meteorological conditions. The content of mycotoxins produced by Fusarium spp. section Liseola is more directly and steadily related to late sowing time, while the contamination of mycotoxins associated to Fusarium spp. section Discolor depends more strongly on the environmental conditions at maize flowering and on hybrid susceptibility.

\section{Introduction}

Over the last decade, the increasing attention paid to safety aspects has affected cereal supply chains: the lack of adequate sanitary parameters pertaining to the presence of contaminants is actually the first cause of the decrease in the market value of cereal commodities (Pinotti and Dell'Orto, 2011). Mycotoxins and other fungal metabolites represent the most insidious safety risks for cereal food and the feed supply chain (Pinotti et al., 2016). The occurrence of these compounds is a topic of great concern, because of the consequent negative health effect on humans and animals (Wild and Gong, 2010). In fact, mycotoxins, which are 
secondary metabolites produced by several filamentous fungi, could cause acute or chronic toxicity in livestock and humans, including carcinogenicity and neurotoxicity, as well as developmental and reproductive toxicity, thus resulting in economic losses (Wu, 2007). Five groups of mycotoxins in particular are considered to be the most economically and toxicologically important throughout the world (Binder et al., 2007): aflatoxins and ochratoxins, which are produced by the fungi of the Aspergillus and Penicillium genera, deoxynivalenol and zearalenone, which are mainly produced by Fusarium graminearum and F. culmorum (section Discolor), and fumonisins, which are mainly produced by $F$. verticillioides and $F$. proliferatum (section Liseola). Regulatory limits have been set by the European Commission (EC) to protect humans and livestock from exposure to the main mycotoxins through cereal consumption (EC, 2006a, 2007, 2011). Moreover, guidance values have been issued for the main toxins produced by Fusarium spp. in products intended for animal feeding (EC, 2006b).

Cereal grains, and maize in particular, are likely to be contaminated before harvesting by all of these mycotoxins (Lee and Ryu, 2017): the occurrence of these metabolites is dependent to a great extent on the co-existence of hybrid susceptibility and certain environmental factors that are favourable to fungal infection, growth and toxinogenesis, such as temperature and moisture at crucial growth stages (GS) (Lancashire et al., 1991). Thus, the application of specific agronomic practices could play a crucial role in minimising the contamination levels of these compounds, by means of the control of their biosynthesis as well as their fungal infection and development during plant cultivation (Munkvold, 2003). Among the agricultural practices employed in maize cultivation, the application of an early sowing time is one of those which has shown the most important impact on the reduction in the risk of mycotoxin contamination. Several studies have shown the clear need for an early sowing time to reduce the risk of contamination by fumonisins (Blandino et al., 2009a, 2009b, 2009c; Camardo Leggieri et al., 2015; Parson and Munkvold, 2012), which are the main mycotoxins commonly detected in maize grain in temperate areas. In addition to fumonisins, it has also been observed that the application of a delayed sowing time may be responsible for an increase in deoxynivalenol (Blandino et al., 2009b) and aflatoxin (Camardo Leggieri et al., 2015) contamination in maize kernels. Thus, the choice of the proper sowing time for each geographic region and hybrid maturity probably represents the best crop technique to control the contamination of maize from the main regulated mycotoxins. However, to date, about 400 different mycotoxins have been identified in different commodities, and several of these have been found in maize (Kovalsky et al., 2016). These fungal metabolites, some of which have been referred to as emerging (Streit et al., 2013), have not yet received detailed scientific attention. The European Food Safety Authority (EFSA) needs data about the occurrence of these mycotoxins in cereals in order to evaluate the risk of exposure of the European population, and to make risk assessments (EFSA, 2010, 2014). Moreover, there is also a great interest in verifying the effect of the Good Agricultural Practices (GAP) that are normally applied in the control of the fumonisin contamination of maize on the control of contamination by other emerging mycotoxins. In this way, it will be possible to set up field programmes that will be able to minimise the overall sanitary risk (related) to maize grains. Since emerging mycotoxins can be produced by other Fusarium species, characterised by a different ecology from that of FB producers, as well as by other fungal species belonging to the Alternaria, Penicillium and Aspergillus genera, more detailed knowledge about the environ- mental and agronomic conditions that promote their occurrence is of great importance.

The aim of this study was to investigate the effect of environmental conditions, related to different growing seasons, of the sowing times and of the type of hybrids with different maturity lengths on the occurrence of emerging mycotoxins and fungal metabolites in maize.

\section{Materials and methods}

\section{Chemicals}

Methanol and acetonitrile (both LC gradient grade) were purchased from J.T. Baker (Deventer, The Netherlands); ammonium acetate (MS grade) and glacial acetic acid (p.a.) were obtained from Sigma-Aldrich (Vienna, Austria). Water was purified successively by means of reverse osmosis and a Milli-Q plus system from Millipore (Molsheim, France).

All the fungal metabolite standard solutions were stored at $-20^{\circ} \mathrm{C}$, and were brought to room temperature before use.

\section{Experimental design and samples}

The effect of the sowing date on emerging mycotoxin occurrence in maize was studied, during the 2014 and 2015 growing seasons, in two experimental areas in North-West Italy, characterised by a sandy-loam soil (Typic Hapludalfs according to the USDA classification). The experiment was conducted in two places: the first experimental year at Buriasco $\left(44^{\circ} 51^{\prime} \mathrm{N}, 7^{\circ} 26^{\prime} \mathrm{E}\right.$; altitude $301 \mathrm{~m})$, whereas the second year at Chivasso $\left(44^{\circ} 12^{\prime} \mathrm{N}, 7^{\circ} 55^{\prime} \mathrm{E}\right.$; altitude $183 \mathrm{~m})$. Daily temperatures and precipitations were measured at a meteorological station located near the experimental areas.

The compared treatments, in both growing seasons, under natural conditions, were factorial combinations of: 2 sowing dates [an early sowing date (at the beginning of April) and a late sowing date (in the middle of May)]; 3 maize hybrids with different lengths of maturity [Pioneer P1208 belonging to FAO maturity class 500 (medium-early maturity hybrid - 125 relative days to maturity); Monsanto DKC6815 belonging to FAO maturity class 600 (full season maturity hybrid - 130 relative days to maturity) and Pioneer PR32B10 belonging to FAO maturity class 600 (full season maturity hybrid - 132 relative days to maturity)].

The treatments were assigned to experimental plots using a completely randomised block design, with three replications. The plot size was $10 \times 3 \mathrm{~m}$, and each plot consisted of 4 rows. The plot alleys, orthogonal to the maize rows, were one meter wide.

Conventional agronomic techniques were adopted for the field experiments in both growing seasons. Briefly, the previous crop was maize, and mechanical sowing was carried out after an autumn ploughing $(30 \mathrm{~cm})$ and disk harrowing to prepare a suitable seedbed. The crop density was approximately 78,000 plants per hectare. All the plots received the same amount of nutrients: 300 , 100 and $100 \mathrm{~kg} \mathrm{ha}^{-1}$ of $\mathrm{N}, \mathrm{P}_{2} \mathrm{O}_{5}$ and $\mathrm{K}_{2} \mathrm{O}$, respectively. Irrigation was carried out by means of the furrow surface method in order to prevent drought stress until the end of the dough stage (GS 87). Weed control was conducted, at a pre-emergence stage, with mesotrione $\left(0.15 \mathrm{~kg} \mathrm{AI} \mathrm{ha}^{-1}\right)$, S-metolachlor $\left(1.25 \mathrm{~kg} \mathrm{AI} \mathrm{ha}^{-1}\right)$ and terbuthylazine $\left(0.75 \mathrm{~kg}\right.$ AI ha $\left.{ }^{-1}\right)\left(\right.$ Lumax $^{\circledR}$, Syngenta Crop Protection S.p.A., Milan, Italy). All the plots were sprayed at GS 75 with pyrethroid lambda-cyhalothrin insecticide (Karate ${ }^{\circledR}$ Zeon, Syngenta Crop Protection S.p.A.) at $0.019 \mathrm{~kg} \mathrm{AI} \mathrm{ha}{ }^{-1}$ using a self- 
propelled ground sprayer (Eurofalcon E140®, Finotto, Italy). The treatment was performed, according to the growth stage, in the middle of July for the early sowing date and in the first decade of August for the late sowing date, in order to minimise the ear injuries caused by the activity of the European Corn Borer (ECB Ostrinia nubilalis, Hübner). The sowing, harvest and the insecticide application dates for each growing season are reported in Table 1.

Ears were collected by hand from $6 \mathrm{~m}^{2}$ (2 rows $\mathrm{x} 4 \mathrm{~m}$ ) of each plot at harvest maturity in order to quantify the grain yield (adjusted to a $14 \%$ moisture content), and to obtain a representative grain sample for the mycotoxin analyses. The ears were shelled using an electric sheller, and kernels from each plot were mixed thoroughly to obtain a random distribution. Samples $(4 \mathrm{~kg})$ were then taken, dried at $60^{\circ} \mathrm{C}$ for 3 days and ground using a ZM 200 Ultra Centrifugal Mill (Retsch GmbH, Haan, Germany), fitted with a 1 $\mathrm{mm}$ aperture sieve to obtain a whole meal, which was then used directly for the extraction and the analysis of the mycotoxins.

The moisture content of the wet maize grain was determined by means of a Dickey-John GAC 2000 grain analysis meter (DickeyJohn Corp. Auburn, IL, USA), using the supplied program.

\section{Entomological and mycological measurements}

The ECB damage severity and fungal ear rot severity were calculated on 20 randomly sampled ears from each plot at harvest maturity. The ECB damage severity was calculated as the percentage of kernels per ear with injuries due to larva activity. A scale of 1 to 7 was used to quantify the percentage interval of surfaces exhibiting visible kernel damage due to larva activity: $1=$ no injuries; $2=1-5 \% ; 3=6-10 \% ; 4=11-20 \% ; 5=21-35 \% ; 6=36-60 \% ; 7$ $>60 \%$ (Blandino et al., 2009c).

The fungal ear rot severity was calculated as the percentage of symptomatic kernels per ear. A scale of 1 to 7 was used to quantify the percentage interval of surfaces exhibiting visible symptoms of the disease: $1=$ no symptoms; $2=1-3 \% ; 3=4-10 \% ; 4=11-25 \%$; $5=26-50 \% ; 6=51-75 \% ; 7>75 \%$ (Blandino et al., 2009c). The ECB damage severity and ear rot severity scores were then converted to percentages of ears exhibiting symptoms, and each score was replaced with the mid-point of the interval.

\section{Multi-mycotoxin liquid chromatography-mass spec- trometry analysis}

Five $g$ representative sub-samples of the milled material were extracted using $20 \mathrm{~mL}$ of a mixture of acetonitrile/water/acetic acid 79:20:1 (v/v/v). After extraction, the samples were centrifuged, diluted 1:1 and injected, as described in detail in Sulyok et al. (2006).

Detection and quantification were performed using a QTrap 5500 LC-MS/MS System (Applied Biosystems, Foster City, CA, USA), equipped with a TurbolonSpray electrospray ionisation (ESI) source and a 1290 Series UPLC System (Agilent, Waldbronn, Germany). Chromatographic separation was per- formed at $25^{\circ} \mathrm{C}$ in a Gemini ${ }^{\circledR} \mathrm{C} 18$-column, $150 \times 4.6 \mathrm{~mm}$ i.d., $5 \mu \mathrm{m}$ particle size, equipped with a $\mathrm{C} 18$ security guard cartridge, $4 \times 3$ mm i.d. (all from Phenomenex, Torrance, CA, USA). The chromatographic and mass spectrometric parameters of the investigated analytes were described in Malachova et al. in 2014. The results of the mycotoxin concentrations were corrected for apparent recoveries.

\section{Statistical analyses}

The normal distribution and the homogeneity of the variance were verified by means of the Kolmogorov-Smirnov normality test and the Levene test, respectively.

All the recorded parameters were compared through an analysis of variance (ANOVA), in which the sowing date and the hybrids were set as independent variables. ANOVA was conducted separately for each growing season. The Ryan-Einot-GabrielWelsh Q (REGWQ) test on treatment means was performed for multiple comparison purposes. The fungal metabolite concentrations were transformed using the $y^{\prime}=\ln (x+1)$ equation to normalise the residuals.

Principal component analysis (PCA) was carried out to investigate the relationships between the main detected mycotoxins. All the data obtained in the two growing seasons were joined together before the PCA was performed. The data were preliminarily standardised by subtracting the means and dividing the results by the standard deviations for each variable.

SPSS for Windows, version 22.0 statistical package (SPSS Inc., Chicago, IL, USA), was used for the statistical analyses.

\section{Results}

Different meteorological trends were observed during the two growing seasons (Table 2). The 2014 growing period showed more abundant rainfall and a lower temperature (expressed as growing degree days, GDDs) than the 2015 growing season during maize ripening (from July to September). In 2014, most abundant rainfall was observed in July, close to the flowering stage of the first sown maize. The high GDDs observed from June to September 2015 led to an anticipated maize harvest in September, whereas in 2014 harvesting took place one month later (Table 1).

ANOVA showed a significant effect of sowing date on the grain yield and grain moisture content for both of the growing seasons: late planting resulted in a $14 \%$ lower grain yield and in a $22 \%$ higher moisture content than the early one (Table 3 ). The full season maturity hybrids DKC6815 and PR32B10 (FAO maturity class $600)$ produced in a significantly higher grain yield than P1208 (FAO maturity class 500) in both growing seasons. The interaction between sowing date and hybrid was never significant.

In the 2015 growing season, the ECB severity was higher in

Table 1. Sowing, insecticide application and harvesting date of the maize hybrids compared in the 2014 and 2015 growing seasons.

$\begin{array}{cccccc}\text { Growing season } & \text { Sowing type } & \text { Sowing date } & \text { Flowering date } & \text { Insecticide application date } & \text { Harvesting date } \\ 2014 & \text { Early } & \text { April 3 } & 7 \text { July } & \text { July 22 } & \text { October 2 } \\ & \text { Late } & \text { May 21 } & \text { 2 August } & \text { August 10 } & \text { October 20 } \\ 2015 & \text { Early } & \text { April 3 } & 5 \text { July } & \text { July 15 } & \text { September 7 } \\ & \text { Late } & \text { May 11 } & 26 \text { July } & \text { August 1 } & \text { September 23 }\end{array}$


the hybrids sown later, whereas the fungal ear rot severity was higher in the late sowing than in the early one in both growing seasons. An increasing ECB severity trend was observed moving from the early maturity hybrid to the late maturity one; the same trend was also observed for fungal ear rot severity in 2015, while the DKC6815 hybrid showed significantly higher disease symptoms than the other hybrids in 2014. The interaction between sowing date and hybrid was never significant, except for fungal ear rot severity in 2015 .

Overall, considering the two growing seasons and the field conditions obtained from the combination of the sowing time and the hybrids, 34 mycotoxins and fungal metabolites produced by Fusarium species were detected: fumonisin B (FBs: sum of $\mathrm{FB}_{1}$, $\mathrm{FB}_{2}, \mathrm{FB}_{3}, \mathrm{FB}_{4}, \mathrm{FB}_{6}$ ), fumonisin $\mathrm{A}$ ( $\mathrm{FAs}$ : sum of $\mathrm{FA}_{1}, \mathrm{FA}_{2}$ ), fusarin $\mathrm{C}$, fusaric acid (FA), bikaverin (BIK), fusaproliferin (FUS), deoxynivalenol and its derivatives (DON: sum of deoxynivalenol, 3-acetyldeoxynivalenol, 15-acetyldeoxynivalenol), deoxynivalenol-3-glucoside (DON-3-G), nivalenol (NIV), culmorin and its derivatives (CULM: sum of culmorin, 5-hydroxyculmorin, 15hydroxyculmorin, 15-hydroxyculmoron), zearalenone (ZEA: sum of zearalenone, $\alpha$-zearalenol, $\beta$-zearalenol, zearalenone-4-sulphate), butenolide (BUT), aurofusarin (AUR), moniliformin $(\mathrm{MON})$, beauvericin (BEA), enniatins (ENNs: sum of ENN B, ENN $B_{1}, E_{N N ~} B_{2}$ ), equisetin (EQU), T-2 toxin and HT-2 toxin.

The $\mathrm{B}$ fumonisins were the most abundant metabolites, with an average contamination of 5593 and $10993 \mu \mathrm{g} \mathrm{kg}^{-1}$ in the 2014 and 2015 growing seasons, respectively. The most abundant compound was fumonisin $\mathrm{B}_{1}(65 \%$ of the total fumonisins), followed by fumonisin $\mathrm{B}_{2}(16 \%), \mathrm{B}_{3}(9 \%)$ and $\mathrm{B}_{4}(8 \%)$. Fumonisin $\mathrm{B}_{6}$ was only found in traces, while the fumonisin $\mathrm{A}$ ( sum of $\mathrm{A}_{1}$ and $\mathrm{A}_{2}$ ) concen-

Table 2. Total rainfall, rainy days and growing degree days measured near the experimental areas from April to October in both the 2014 and 2015 growing seasons.

\begin{tabular}{|c|c|c|c|c|}
\hline Growing season & Month & Rainfall (mm) & Rainy days (n) & $\mathrm{GDDs}^{\circ}\left({ }^{\circ} \mathrm{C}\right)$ \\
\hline 2014 & $\begin{array}{l}\text { April } \\
\text { May } \\
\text { June } \\
\text { July } \\
\text { August } \\
\text { September } \\
\text { October } \\
\text { July - September }\end{array}$ & $\begin{array}{c}71 \\
91 \\
102 \\
153 \\
50 \\
132 \\
24 \\
335\end{array}$ & $\begin{array}{c}12 \\
13 \\
12 \\
18 \\
9 \\
11 \\
9 \\
38\end{array}$ & $\begin{array}{l}163 \\
210 \\
324 \\
337 \\
345 \\
277 \\
187 \\
959\end{array}$ \\
\hline 2015 & $\begin{array}{l}\text { April } \\
\text { May } \\
\text { June } \\
\text { July } \\
\text { August } \\
\text { September } \\
\text { October } \\
\text { July - September }\end{array}$ & $\begin{array}{c}71 \\
76 \\
64 \\
21 \\
80 \\
64 \\
160 \\
164\end{array}$ & $\begin{array}{c}10 \\
11 \\
14 \\
2 \\
15 \\
10 \\
19 \\
27\end{array}$ & $\begin{array}{c}162 \\
257 \\
356 \\
444 \\
378 \\
252 \\
133 \\
1074\end{array}$ \\
\hline
\end{tabular}

GDDs, growing degree days. ${ }^{\circ}$ Accumulated growing degree days for each month using a $10^{\circ} \mathrm{C}$ base. Source: Agrometeorological Network of Piedmont - Piedmont Region - Assessorato Agricoltura - Settore Fitosanitario sezione di Agrometeorologia".

Table 3. Effect of sowing date and hybrid maturity length on grain yield, grain moisture, European corn borer severity and fungal ear rot severity at harvest.

\begin{tabular}{|c|c|c|c|c|c|c|}
\hline Growing season & $\begin{array}{l}\text { Source } \\
\text { of variation }\end{array}$ & Treatment & 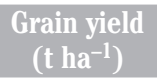 & $\begin{array}{c}\text { Grain moisture } \\
(\%)\end{array}$ & $\begin{array}{c}\text { ECB severity }{ }^{\circ} \\
(\%)\end{array}$ & $\begin{array}{l}\text { Fungal ear rot } \\
\text { severity\# (\%) }\end{array}$ \\
\hline 2014 & $\begin{array}{l}\text { Sowing date } \\
\text { Hybrid } \\
\text { Sowing date } \times \text { Hybrid }\end{array}$ & $\begin{array}{c}\text { Early } \\
\text { Late } \\
\text { P (F) } \\
\text { P1208 } \\
\text { DKC6815 } \\
\text { PR32B10 } \\
\text { P (F) } \\
\text { P (F) }\end{array}$ & $\begin{array}{c}17.5^{\mathrm{a}} \\
14.8^{\mathrm{b}} \\
0.001 \\
13.4^{\mathrm{b}} \\
16.7^{\mathrm{a}} \\
18.3^{\mathrm{a}} \\
<0.001 \\
0.351\end{array}$ & $\begin{array}{l}25.7^{\mathrm{b}} \\
35.0^{\mathrm{a}} \\
<0.001 \\
29.0^{\mathrm{b}} \\
32.3^{\mathrm{a}} \\
29.8^{\mathrm{b}} \\
<0.001 \\
0.735\end{array}$ & $\begin{array}{c}2.3^{\mathrm{a}} \\
2.4^{\mathrm{a}} \\
0.900 \\
0.3^{\mathrm{c}} \\
2.1^{\mathrm{b}} \\
4.8^{\mathrm{a}} \\
<0.001 \\
0.531\end{array}$ & $\begin{array}{c}6.4^{\mathrm{b}} \\
10.4^{\mathrm{a}} \\
<0.001 \\
4.2^{\mathrm{b}} \\
15.9^{\mathrm{a}} \\
5.1^{\mathrm{b}} \\
<0.001 \\
0.174\end{array}$ \\
\hline 2015 & Sowing date $\times$ Hybrid & $\begin{array}{c}\text { Early } \\
\text { Late } \\
\text { P (F) } \\
\text { P1208 } \\
\text { DKC6815 } \\
\text { PR32B10 } \\
\text { P (F) } \\
\text { P (F) }\end{array}$ & $\begin{array}{c}15.7^{\mathrm{a}} \\
13.8^{\mathrm{b}} \\
0.001 \\
12.3^{\mathrm{b}} \\
16.4^{\mathrm{a}} \\
15.5^{\mathrm{a}} \\
<0.001 \\
0.884\end{array}$ & $\begin{array}{c}26.6^{\mathrm{b}} \\
28.5^{\mathrm{a}} \\
<0.001 \\
26.6^{\mathrm{b}} \\
28.1^{\mathrm{a}} \\
28.1^{\mathrm{a}} \\
0.010 \\
0.268\end{array}$ & $\begin{array}{c}0.5^{\mathrm{b}} \\
3.2^{\mathrm{a}} \\
0.001 \\
0.6^{\mathrm{b}} \\
2.7^{\mathrm{a}} \\
2.4^{\mathrm{a}} \\
0.030 \\
0.113\end{array}$ & $\begin{aligned} & 0.4^{\mathrm{b}} \\
& 4.2^{\mathrm{a}} \\
< & 0.001 \\
& 0.8^{\mathrm{c}} \\
& 2.6^{\mathrm{b}} \\
3.5^{\mathrm{a}} & <0.001 \\
& 0.001\end{aligned}$ \\
\hline
\end{tabular}

ECB, European corn borer. ${ }^{\circ} \mathrm{ECB}$ severity was calculated as the percentage of kernels per ear with insect injuries, considering 20 ears per plot; $\#$ fungal ear rot severity was calculated as the percentage of kernels per ear with fungal disease symptoms, considering 20 ears per plot; ${ }^{\mathrm{a}-\mathrm{b}}$ means followed by different letters are significantly different (the level of significance is shown in the table). The sowing date values are based on 9 replicates ( 3 hybrids $x 3$ replications), while the hybrid values are based on 6 replicates ( 2 sowing dates $\times 3$ replications). 
tration was $2 \%$ of the total fumonisin contamination.

In addition to FBs, other metabolites produced by Fusarium verticillioides and $F$. proliferatum, such as FA, BIK and FUS, were detected in all of the samples, with an average contamination of $400 \mu \mathrm{g} \mathrm{kg}^{-1}, 237 \mu \mathrm{g} \mathrm{kg}^{-1}$ and $551 \mu \mathrm{g} \mathrm{kg}^{-1}$, respectively. The occurrence of fusarin $\mathrm{C}$ was found in $61 \%$ of the samples, with an average contamination of $75 \mu \mathrm{g} \mathrm{kg}^{-1}$.

CULM, DON, DON-3-G and ZEA were detected in all of the samples in the 2014 growing season, with an average contamination of $5239 \mu \mathrm{g} \mathrm{kg}^{-1}, 3669 \mu \mathrm{g} \mathrm{kg}^{-1}, 1412 \mu \mathrm{g} \mathrm{kg}-1$ and $1508 \mu \mathrm{g} \mathrm{kg} \mathrm{kg}^{-1}$, respectively. In the 2015 growing season, these metabolites ranged from $44 \%$ to $89 \%$ of the cases, with an average contamination of $447 \mu \mathrm{g} \mathrm{kg}^{-1}, 274 \mu \mathrm{g} \mathrm{kg}^{-1}, 103 \mu \mathrm{g} \mathrm{kg}^{-1}$ and $41 \mu \mathrm{g} \mathrm{kg}^{-1}$, respectively for CULM, DON, DON-3-G and ZEA. Other mycotoxins produced by $F$. graminearum and $F$. culmorum, such as NIV and BUT, were on average found at lower concentrations.

As far as the modified mycotoxins are concerned, the ratio between 3-acetyldeoxynivalenol and 15-acetyldeoxynivalenol and DON in all of the compared situations was 22 and 3\%, respectively. The DON-3-G/DON ratio (on average 40\%) was similar for both of the growing seasons and sowing date, but resulted to be higher in full season maturity hybrids than the medium-early one. The hydroxylated forms of culmorin (5-hydroxyculmorin, 15hydroxyculmorin, 15 -hydroxyculmoron) accounted for $67 \%$ of the total CULM, and their ratio was stable in the compared experimental trials.

Among the mycotoxins produced by other Fusarium species, MON and BEA had been produced by Fusarium species fungi belonging to both the Liseola (F. proliferatum and F. subglutinans) and Roseum sections (F. avenaceum). MON and BEA were found in similar contents in both growing seasons, with an average contamination of $264 \mu \mathrm{g} \mathrm{kg}^{-1}$ and $125 \mu \mathrm{g} \mathrm{kg}^{-1}$, respectively. On the other hand, like DON, the AUR contamination was different in the two growing seasons. Concentrations of $15,348 \mu \mathrm{g} \mathrm{kg}^{-1}$ and 413 $\mu \mathrm{g} \mathrm{kg}-1$ were observed in the 2014 and 2015 growing seasons, respectively. EQU, which is produced by $F$. equiseti, was found in $97 \%$ of the cases, with an average content of $62 \mu \mathrm{g} \mathrm{kg}^{-1}$, while T2 and HT-2 toxins, which are produced by $F$. sprorotrichioides, $F$. langsaethiae and F. poae, were found in $36 \%$ of the samples, with an average concentration of $20 \mu \mathrm{g} \mathrm{kg}^{-1}$ (sum of the T-2 and HT-2 toxins), and a similar content of both toxins. Finally, ENNs were found at very low contamination levels in all the samples of the compared production situations.

Among the toxins produced by the Alternaria species, alternariol (AOH), alternariol methyl ether (AME) and tentoxin (TENT) were found in traces in both growing seasons in less than $30 \%$ of the samples.

In addition to the meteorological conditions, the concentrations of mycotoxins and fungal metabolites were clearly influenced by the sowing times and by the type of hybrid considered. In both growing seasons, a late sowing time significantly increased all the mycotoxins produced by $F$. verticillioides and $F$. proliferatum (Table 4). On average, the content of FBs, FAs, Fusarin C, FA, BIK and FUS in the 2014 growing season resulted to be 2.1, 2.3, 2.9, 1.7, 2.1 and 2.8 times higher in the late sowing than in the early one. The contamination of all these toxins increased more (from 4 to 8 times) in the late sowing time in 2015. As far as the type of hybrid is concerned, the full season maturity hybrids, and particularly the PR32B10 hybrid, which is characterised by the longest cycle, often resulted in a significantly higher content of FBs, FAs, Fusarin C, BIK and FUS than the medium-early maturity hybrid (P1208). Only for FA contamination a negative relationship with hybrid precocity was not observed clearly in both growing seasons. In 2014, the interaction between sowing date and hybrid for all these metabolites was never significant. However, a significant interaction was observed for FBs, FAs and Fusarin C in 2015. As far as the content of FBs is concerned, the lowest contamination was observed in DKC6815, in the early sowing time, whereas a significantly higher contamination was observed in the late sowing period for both DKC6815 and PR32B10 than for

Table 4. Effect of sowing date and hybrid maturity length on the occurrence of mycotoxins produced mainly by Fusarium verticillioides and Fusarium proliferatum.

\begin{tabular}{|c|c|c|c|c|c|c|c|c|c|c|c|c|c|c|}
\hline \multirow[t]{2}{*}{ Year } & \multirow{2}{*}{$\begin{array}{l}\text { Source of } \\
\text { variation }\end{array}$} & \multirow[t]{2}{*}{ Treatment } & \multicolumn{2}{|c|}{ FBs } & \multicolumn{2}{|c|}{ FAs } & \multicolumn{2}{|c|}{ Fusarin C } & \multicolumn{2}{|c|}{ FA } & \multicolumn{2}{|c|}{ BIK } & \multicolumn{2}{|c|}{ FUS } \\
\hline & & & $\mathrm{T}$ & $\begin{array}{c}\mathrm{N} \\
\left.\lg \mathrm{kg}^{-1}\right)\end{array}$ & $\mathrm{T}$ & $\begin{array}{c}\mathrm{N} \\
\left.\mathrm{g} \mathrm{kg}^{-1}\right)\end{array}$ & $\mathrm{T}$ & $\begin{array}{c}\mathrm{N} \\
\left.\mu \mathrm{g} \mathrm{kg}^{-1}\right)\end{array}$ & $\mathrm{T}$ & $\begin{array}{c}\mathrm{N} \\
\left(\mu \mathrm{g} \mathrm{kg}^{-1}\right)\end{array}$ & $\mathrm{T}$ & $\begin{array}{c}\mathrm{N} \\
\left(\mu \mathrm{g} \mathrm{kg}^{-1}\right)\end{array}$ & $\mathrm{T}$ & $\begin{array}{c}\mathrm{N} \\
(\mu \mathrm{g} \mathrm{kg}\end{array}$ \\
\hline \multirow[t]{8}{*}{2014} & \multirow[t]{3}{*}{ Sowing date } & Early & $8.1^{\mathrm{b}}$ & 3572 & $4.1^{\mathrm{b}}$ & 67 & $3.4^{\mathrm{a}}$ & 68 & $5.0^{\mathrm{b}}$ & 159 & $4.8^{b}$ & 139 & $5.7^{\mathrm{b}}$ & 367 \\
\hline & & Late & $8.8^{\mathrm{a}}$ & 7614 & $4.9^{\mathrm{a}}$ & 155 & $4.7^{\mathrm{a}}$ & 118 & $6.1^{\mathrm{a}}$ & 466 & $5.6^{\mathrm{a}}$ & 294 & $6.6^{\mathrm{a}}$ & 1025 \\
\hline & & $P(F)$ & 0.013 & - & 0.002 & - & 0.091 & - & $<0.001$ & - & 0.003 & - & 0.011 & - \\
\hline & \multirow[t]{4}{*}{ Hybrid } & P1208 & $8.4^{\mathrm{a}}$ & 4910 & $4.1^{\mathrm{b}}$ & 64 & $3.7^{\mathrm{a}}$ & 76 & $5.4^{\mathrm{a}}$ & 321 & $5.0^{\mathrm{a}}$ & 196 & $5.3^{b}$ & 250 \\
\hline & & DKC6815 & $8.0^{\mathrm{b}}$ & 3538 & $4.3^{b}$ & 81 & $3.9^{\mathrm{a}}$ & 90 & $5.4^{\mathrm{a}}$ & 244 & $5.1^{\mathrm{a}}$ & 184 & $6.6^{\mathrm{a}}$ & 841 \\
\hline & & PR32B10 & $8.9^{\mathrm{a}}$ & 8332 & $5.1^{\mathrm{a}}$ & 187 & $4.7^{\mathrm{a}}$ & 112 & $5.8^{\mathrm{a}}$ & 372 & $5.5^{\mathrm{a}}$ & 269 & $6.6^{\mathrm{a}}$ & 998 \\
\hline & & $\mathrm{P}(\mathrm{F})$ & 0.033 & - & 0.002 & - & 0.462 & - & 0.148 & - & 0.294 & - & 0.003 & - \\
\hline & Sowing date $\times$ Hybrid & $P(F)$ & 0.621 & - & 0.405 & - & 0.674 & - & 0.053 & - & 0.777 & - & 0.968 & - \\
\hline \multirow[t]{8}{*}{2015} & \multirow{3}{*}{ Sowing date } & Early & $7.0^{\mathrm{b}}$ & 2030 & $2.8^{\mathrm{b}}$ & 45 & $<\mathrm{LOQ}^{\mathrm{b}}$ & $<\mathrm{LOQ}$ & $3.8^{b}$ & 105 & $4.4^{\mathrm{b}}$ & 98 & $1.3^{\mathrm{b}}$ & 62 \\
\hline & & Late & $9.4^{\mathrm{a}}$ & 19956 & $5.5^{\mathrm{a}}$ & 400 & $3.3^{\mathrm{a}}$ & 111 & $6.7^{\mathrm{a}}$ & 871 & $5.8^{\mathrm{a}}$ & 419 & $6.4^{\mathrm{a}}$ & 751 \\
\hline & & $P(F)$ & $<0.001$ & - & $<0.001$ & - & $<0.001$ & - & $<0.001$ & - & $<0.001$ & - & $<0.001$ & - \\
\hline & \multirow[t]{4}{*}{ Hybrid } & P1208 & $7.7^{\mathrm{b}}$ & 2552 & $3.6^{\mathrm{b}}$ & 40 & $<\mathrm{LOQ}^{\mathrm{b}}$ & $<\mathrm{LOQ}$ & $6.0^{\mathrm{a}}$ & 643 & $4.5^{\mathrm{b}}$ & 97 & $2.8^{b}$ & 141 \\
\hline & & DKC6815 & $7.6^{\mathrm{b}}$ & 11055 & $3.4^{\mathrm{b}}$ & 281 & $2.5^{\mathrm{a}}$ & 75 & $4.1^{\mathrm{b}}$ & 403 & $5.3^{\mathrm{a}}$ & 337 & $3.4^{\mathrm{b}}$ & 500 \\
\hline & & PR32B10 & $9.2^{\mathrm{a}}$ & 19371 & $5.4^{\mathrm{a}}$ & 347 & $2.5^{\mathrm{a}}$ & 91 & $5.7^{\mathrm{a}}$ & 418 & $5.5^{\mathrm{a}}$ & 342 & $5.3^{\mathrm{a}}$ & 579 \\
\hline & & $P(F)$ & 0.002 & - & $<0.001$ & - & $<0.001$ & - & 0.037 & - & 0.020 & - & 0.023 & - \\
\hline & Sowing date $\times$ Hybrid & $P(F)$ & 0.001 & 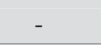 & $<0.001$ & - & $<0.001$ & 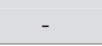 & 0.059 & 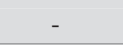 & 0.134 & 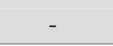 & 0.086 & - \\
\hline
\end{tabular}

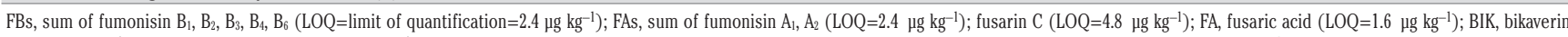
$\left(\mathrm{LOQ}=8 \mu \mathrm{g} \mathrm{kg}^{-1}\right)$; FUS, fusaproliferin ( $\left.\mathrm{LOQ}=40 \mu \mathrm{g} \mathrm{kg}^{-1}\right)$. The mycotoxin contamination means reported are transformed $\left[\mathrm{T} ; \mathrm{y}^{\prime}=\ln (\mathrm{x}+1)\right]$ and non-transformed $(\mathrm{N})$ values. ${ }^{\mathrm{a}, \mathrm{b}} \mathrm{Means}$ followed by different letters are significantly different (the level of significance is shown in the table). The sowing date values are based on 9 replicates ( 3 hybrids $\mathrm{x} 3$ replications), while the hybrid values are based on 6 replicates ( 2 sowing dates $\times 3$ replications). 
P1208 (Figure 1). In both growing seasons, the sowing date also clearly affected the mycotoxin contents produced by $F$. graminearum and F. culmorum (Table 5). During the 2014 growing season, which was characterised by abundant rainfall and cold temperatures during the flowering stage of the early planted maize, the early sowing date resulted in a significantly higher contamination of DON (+53\%), DON-3-G (+64\%), NIV (+3 times), CULM $(+42 \%), \mathrm{ZEA}(+22 \%)$ and BUT $(+35 \%)$ than for the late sowing date. Conversely, in 2015, the early sowing significantly reduced the DON, DON-3-G, CULM, ZEA and BUT contents by 78, 85, 84,88 and $84 \%$, respectively, compared to the late one. In the same year, no significant difference was observed for NIV for the compared sowing dates. As far as hybrid susceptibility is concerned, the DKC6815 cultivar showed the highest contamination level for all these mycotoxins and metabolites in both growing seasons, with the exception of NIV in 2015. No significant differences were reported for DON-3-G, NIV, ZEA or BUT in the 2015 growing season for the full season maturity hybrids. No significant difference was observed between the medium-early maturity hybrid, P1208, and the full season maturity hybrid, PR32B10, for any of the mycotoxins, with the exception of DON-3-G in 2014 and ZEA in 2015 .

The interaction between sowing date and hybrid for these metabolites was never significant, with the exception of NIV in 2014 and CULM in the 2015 growing season. In particular, as shown in Figure 2, the CULM content in the 2015 growing season significantly increased with the late sowing time, but only for the P1208 hybrid.

As far as the mycotoxins and fungal metabolites produced by other Fusarium species are concerned, the sowing date significantly affected the contamination of AUR, MON, BEA and the T-2 and
HT-2 toxins (Table 6). The late sowing in 2015 increased the AUR, MON and BEA contents by 8.9, 3.3 and 11.4 times, respectively. Conversely, in 2014, the MON, T-2 and HT-2 contents were significantly higher in the early sowing time than in the late one. The occurrence of ENNs and EQU was never affected by the sowing time. As far as hybrid susceptibility is concerned, a significantly higher AUR content was found in DKC6815 in 2014, while EQU

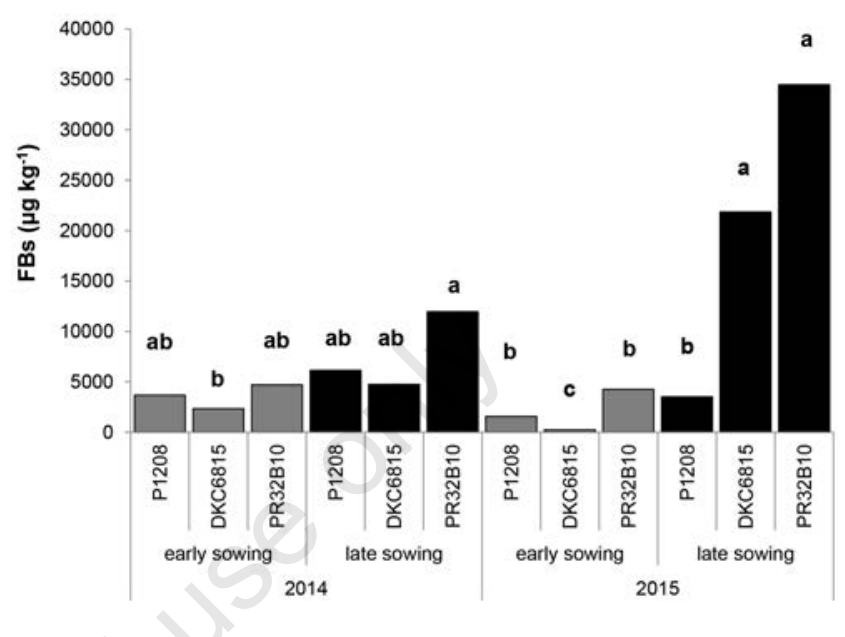

Figure 1. Effect of interaction between sowing date and hybrid maturity length on fumonisin B contamination. Means followed by different letters within each year are significantly different $(P<0.01)$. The reported data are the means of 3 replications.

Table 5. Effect of sowing date and hybrid maturity length on the occurrence of mycotoxins produced mainly by Fusarium graminearum and Fusarium culmorum.

\begin{tabular}{|c|c|c|c|c|c|c|c|c|c|c|c|c|c|c|}
\hline \multirow[t]{2}{*}{ Year } & \multirow{2}{*}{$\begin{array}{l}\text { Source of } \\
\text { variation }\end{array}$} & \multirow[t]{2}{*}{ Treatment } & \multicolumn{2}{|c|}{ DON } & \multicolumn{2}{|c|}{ DON-3-G } & \multicolumn{2}{|c|}{ NIV } & \multicolumn{2}{|c|}{ CULM } & \multicolumn{2}{|c|}{ ZEA } & \multicolumn{2}{|c|}{ BUT } \\
\hline & & & In & $\begin{array}{c}\mathrm{N} \\
\mathrm{g} \mathbf{~ k g}\end{array}$ & $\mathrm{T}$ & $\stackrel{\mathrm{N}}{\mathrm{g} \mathrm{kg}^{-1}}$ & $\mathrm{~T}$ & $\begin{array}{c}\mathrm{N} \\
\left.\lg \mathrm{kg}^{-1}\right)\end{array}$ & $\mathrm{T}$ & $\begin{array}{c}\mathrm{N} \\
\left(\mu \mathrm{g} \mathrm{kg}^{-1}\right)\end{array}$ & $\mathrm{T}$ & $\begin{array}{c}\mathrm{N} \\
\left(\mu \mathrm{kg} \mathrm{kg}^{-1}\right)\end{array}$ & $\mathrm{T}$ & $\begin{array}{c}\mathrm{N} \\
\left(\mu \mathrm{g} \mathrm{kg}^{-1}\right)\end{array}$ \\
\hline \multirow[t]{8}{*}{2014} & \multirow[t]{3}{*}{ Sowing date } & Early & $8.2^{\mathrm{a}}$ & 4443 & $7.1^{\mathrm{a}}$ & 1758 & $2.9^{\mathrm{a}}$ & 29.1 & $8.5^{\mathrm{a}}$ & 6159 & $7.0^{\mathrm{a}}$ & 1660 & $5.8^{\mathrm{a}}$ & 338 \\
\hline & & Late & $7.6^{\mathrm{b}}$ & 2896 & $6.4^{\mathrm{b}}$ & 1066 & $1.2^{\mathrm{b}}$ & 7.2 & $8.0^{\mathrm{b}}$ & 4319 & $6.4^{\mathrm{b}}$ & 1356 & $5.4^{\mathrm{b}}$ & 250 \\
\hline & & $\mathrm{P}(\mathrm{F})$ & 0.016 & - & 0.004 & - & 0.001 & - & 0.046 & - & 0.050 & - & 0.004 & \\
\hline & \multirow[t]{4}{*}{ Hybrid } & P1208 & $7.5^{b}$ & 2251 & $5.8^{\mathrm{c}}$ & 387 & $1.1^{\mathrm{b}}$ & 4.4 & $7.9^{\mathrm{b}}$ & 3359 & $5.7^{\mathrm{b}}$ & 508 & $5.5^{\mathrm{b}}$ & 242 \\
\hline & & DKC6815 & $8.8^{\mathrm{a}}$ & 6818 & $8.0^{\mathrm{a}}$ & 3157 & $3.5^{\mathrm{a}}$ & 37.8 & $9.2^{\mathrm{a}}$ & 9724 & $8.1^{\mathrm{a}}$ & 3491 & $6.0^{\mathrm{a}}$ & 425 \\
\hline & & PR32B10 & $7.4^{\mathrm{b}}$ & 1939 & $6.4^{\mathrm{b}}$ & 692 & $1.6^{\mathrm{b}}$ & 12.2 & $7.7^{\mathrm{b}}$ & 2634 & $6.2^{\mathrm{b}}$ & 526 & $5.3^{b}$ & 215 \\
\hline & & $\mathrm{P}(\mathrm{F})$ & $<0.001$ & - & $<0.001$ & - & 0.001 & - & 0.001 & - & $<0.001$ & - & $<0.001$ & - \\
\hline & Sowing date $\times$ Hybrid & $\mathrm{P}(\mathrm{F})$ & 0.366 & - & 0.351 & - & 0.039 & - & 0.384 & - & 0.151 & - & 0.121 & - \\
\hline \multirow[t]{8}{*}{2015} & \multirow[t]{3}{*}{ Sowing date } & Early & $1.4^{\mathrm{b}}$ & 99 & $1.7^{\mathrm{b}}$ & 26 & $0.5^{\mathrm{a}}$ & 1.9 & $3.1^{\mathrm{b}}$ & 123 & $1.1^{\mathrm{b}}$ & 9 & $3.0^{\mathrm{b}}$ & 34 \\
\hline & & Late & $4.0^{\mathrm{a}}$ & 450 & $4.7^{\mathrm{a}}$ & 179 & $<\mathrm{LOQ}^{\mathrm{a}}$ & $<\mathrm{LOQ}$ & $6.3^{\mathrm{a}}$ & 772 & $3.7^{\mathrm{a}}$ & 73 & $5.0^{\mathrm{a}}$ & 214 \\
\hline & & $\mathrm{P}(\mathrm{F})$ & 0.036 & - & 0.001 & - & 0.184 & - & $<0.001$ & - & $<0.001$ & - & 0.001 & - \\
\hline & \multirow[t]{4}{*}{ Hybrid } & P1208 & $1.1^{\mathrm{b}}$ & 30 & $1.8^{b}$ & 20 & $0.3^{\mathrm{a}}$ & 1.2 & $3.5^{\mathrm{b}}$ & 286 & $1.1^{\mathrm{b}}$ & 5 & $3.1^{\mathrm{b}}$ & 44 \\
\hline & & DKC6815 & $5.5^{\mathrm{a}}$ & 670 & $4.4^{\mathrm{a}}$ & 202 & $<\mathrm{LOQ}^{\mathrm{a}}$ & $<\mathrm{LOQ}$ & $6.1^{\mathrm{a}}$ & 840 & $3.4^{\mathrm{a}}$ & 72 & $4.9^{\mathrm{a}}$ & 238 \\
\hline & & PR32B10 & $1.4^{\mathrm{b}}$ & 123 & $3.4^{\mathrm{ab}}$ & 87 & $0.4^{\mathrm{a}}$ & 1.6 & $4.5^{b}$ & 217 & $2.7^{\mathrm{a}}$ & 46 & $4.0^{\mathrm{ab}}$ & 89 \\
\hline & & $\mathrm{P}(\mathrm{F})$ & 0.013 & - & 0.024 & - & 0.616 & - & 0.006 & - & 0.007 & - & 0.030 & - \\
\hline & Sowing date $\times$ Hybrid & $\mathrm{P}(\mathrm{F})$ & 0.963 & - & 0.753 & - & 0.616 & - & 0.038 & . & 0.489 & - & 0.773 & - \\
\hline
\end{tabular}

DON, sum of deoxynivalenol (LOQ=limit of quantification=1.2 $\mu \mathrm{g} \mathrm{kg}^{-1}$ ) and deoxynivalenol derivatives: 3-acetyldeoxynivalenol (LOQ=1.2 $\left.\mu \mathrm{g} \mathrm{kg}{ }^{-1}\right)$ and 15-acetyldeoxynivalenol (LOQ=1.2 $\mu \mathrm{g} \mathrm{kg}{ }^{-1}$ ); DON-3-G, deoxynivalenol-3-glucoside ( $\mathrm{LOQ}=0.8 \mu \mathrm{g} \mathrm{kg}^{-1}$ ); NIV, nivalenol ( $\mathrm{LOQ}=1.2 \mu \mathrm{g} \mathrm{kg}^{-1}$ ); CULM=sum of culmorin ( $\mathrm{LOQ}=8 \mu \mathrm{g} \mathrm{kg}^{-1}$ ) and culmorin derivatives: 5 -hydroxyculmorin $\left(\mathrm{LOQ}=40 \mu \mathrm{g} \mathrm{kg}^{-1}\right.$ ), 15 -hydroxyculmorin $(\mathrm{LOQ}=4 \mu \mathrm{g}$ $\mathrm{kg}^{-1}$ ), 15-hydroxyculmoron ( $\mathrm{LOQ}=24 \mathrm{ug} \mathrm{kg}^{-1}$ ); ZEA, sum of zearalenone ( $\mathrm{LOQ}=0.12 \mu \mathrm{g} \mathrm{kg}-1$ ) and zearalenone derivatives: $\alpha$-zearalenol $\left(\mathrm{LOQ}=0.8 \mu \mathrm{g} \mathrm{kg}{ }^{-1}\right.$ ), $\beta$-zearalenol $\left(\mathrm{LOQ}^{-}=1.2 \mu \mathrm{g} \mathrm{kg}^{-1}\right)$, zearalenone-4-sulphate $\left(\mathrm{LOQ}=1.6 \mu \mathrm{g} \mathrm{kg}^{-1}\right)$; BUT, butenolide ( $\mathrm{LOQ}=5.6 \mu \mathrm{g} \mathrm{kg}^{-1}$ ). The mycotoxin contamination means reported are transformed [T; $\left.\mathrm{y}^{\prime}=\ln (\mathrm{x}+1)\right]$ and non-transformed $(\mathrm{N})$ values. ${ }^{\mathrm{a}-\mathrm{c}} \mathrm{Means}$ followed by different letters are significantly different (the level of significance is shown in the table). The sowing date values are based on 9 replicates ( 3 hybrids $\times 3$ replications), while the hybrid values are based on 6 replicates ( 2 sowing dates $\times 3$ replications). 
was significantly lower in P1208 than in the full season maturity hybrids. A significantly higher contamination of MON was found in PR32B10 than P1208 in 2015. No significant differences between hybrids were observed for BEA, ENNs or for the T-2 and HT-2 toxins. The interaction between sowing date and hybrid was never significant for any of these metabolites.

PCA was carried out to investigate the relationships between

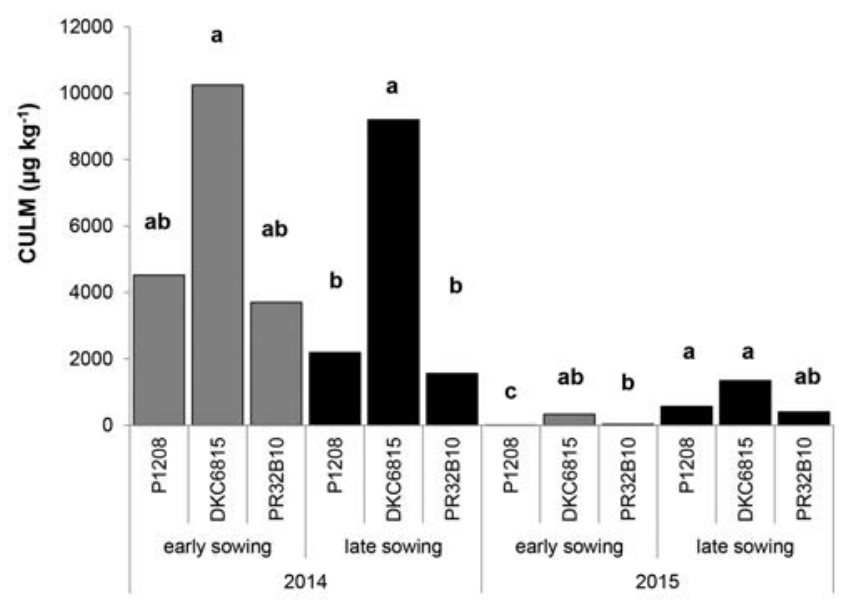

Figure 2. Effect of interaction between sowing date and hybrid maturity length on culmorin and culmorin derivates (5-hydroxyculmorin, 15-hydroxyculmorin and 15-hydroxyculmoron) contamination. Means followed by different letters within each year are significantly different $(P<0.01)$. The reported data are the means of 3 replications. the main detected mycotoxins, as it allows the maize samples to be clustered according to similar mycotoxin contaminations. The results of the PCA performed with the main metabolites detected in the two growing seasons were used to produce a loading plot in which the two first principal components explained $43 \%$ and $33 \%$ of the total variations of the samples (Figure 3). It can be assumed that the first component differentiated the samples according to

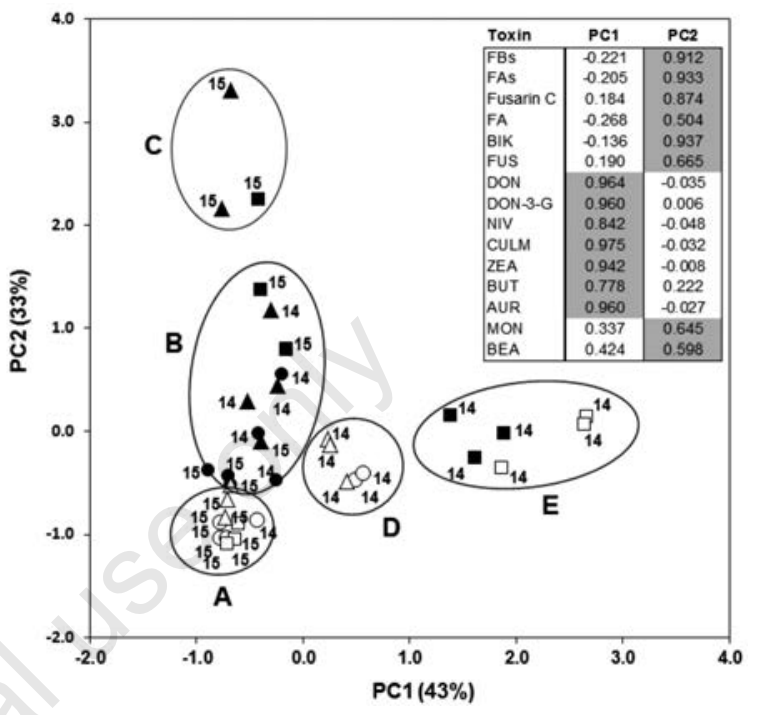

Figure 3. Score plots of maize samples $(\mathrm{N}=36)$ marked according to the hybrid type (circle: P1208 hybrid; square: DKC6815 hybrid; triangle: PR32B10 hybrid), sowing date (white: early sowing date; black: late sowing date) and growing season $(14=2014,15=2015)$. The loadings (highlighted values $>|0.5|)$ of each parameter are reported with the two first principal components.

Table 6. Effect of sowing date and hybrid maturity length on the occurrence of mycotoxins produced by other Fusarium species.

\begin{tabular}{|c|c|c|c|c|c|c|c|c|c|c|c|c|c|c|}
\hline \multirow[t]{2}{*}{ Year } & \multirow{2}{*}{$\begin{array}{l}\text { Source of } \\
\text { variation }\end{array}$} & \multirow[t]{2}{*}{ Treatment } & \multicolumn{2}{|c|}{ AUR } & \multicolumn{2}{|c|}{ MON } & \multicolumn{2}{|c|}{ BEA } & \multicolumn{2}{|c|}{ ENNs } & \multicolumn{2}{|c|}{ EQU } & \multicolumn{2}{|c|}{ T-2 and HT-2 toxin } \\
\hline & & & $\mathrm{T}$ & $\begin{array}{c}\mathrm{N} \\
\left.\mu \mathrm{g} \mathrm{kg}^{-1}\right)\end{array}$ & $\mathrm{T}$ & $\begin{array}{c}\mathrm{N} \\
(\mu \mathrm{g} \mathrm{kg-1})\end{array}$ & $\mathrm{T}$ & $\underset{\left(\mu g \mathrm{~kg}^{-1}\right)}{\mathrm{N}}$ & $\mathrm{T}$ & $\begin{array}{c}\mathrm{N} \\
\left(\mu \mathrm{g} \mathrm{kg}^{-1}\right)\end{array}$ & $\mathrm{T}$ & $\begin{array}{c}\mathrm{N} \\
\left(\mu \mathrm{g} \mathrm{kg}^{-1}\right)\end{array}$ & $\mathrm{T}$ & $\begin{array}{c}\mathrm{N} \\
\left(\mu \mathrm{g} \mathrm{kg}^{-1}\right)\end{array}$ \\
\hline \multirow[t]{8}{*}{2014} & \multirow[t]{3}{*}{ Sowing date } & Early & $9.3^{\mathrm{a}}$ & 16527 & $5.7^{\mathrm{a}}$ & 384 & $5.0^{\mathrm{a}}$ & 186 & $0.1^{\mathrm{a}}$ & 0.2 & $2.7^{\mathrm{a}}$ & 63 & $1.9^{\mathrm{a}}$ & 12.7 \\
\hline & & Late & $8.8^{\mathrm{a}}$ & 14169 & $4.7^{\mathrm{b}}$ & 150 & $5.0^{\mathrm{a}}$ & 148 & $0.2^{\mathrm{a}}$ & 0.7 & $3.5^{\mathrm{a}}$ & 83 & $0.2^{\mathrm{b}}$ & 0.5 \\
\hline & & $P(F)$ & 0.137 & - & 0.007 & - & 0.942 & - & 0.644 & - & 0.637 & - & 0.007 & - \\
\hline & \multirow[t]{4}{*}{ Hybrid } & P1208 & $8.3^{b}$ & 6229 & $4.9^{\mathrm{a}}$ & 174 & $4.8^{\mathrm{a}}$ & 148 & $<\mathrm{LOQ}^{\mathrm{a}}$ & $<\mathrm{LOQ}$ & $1.7^{\mathrm{a}}$ & 8 & $1.4^{\mathrm{a}}$ & 7.7 \\
\hline & & DKC6815 & $10.4^{\mathrm{a}}$ & 33831 & $5.5^{\mathrm{a}}$ & 425 & $5.3^{\mathrm{a}}$ & 219 & $<\mathrm{LOQ}^{\mathrm{a}}$ & $<\mathrm{LOQ}$ & $3.2^{\mathrm{a}}$ & 95 & $0.9^{\mathrm{a}}$ & 3.1 \\
\hline & & PR32B10 & $8.5^{\mathrm{b}}$ & 5984 & $5.2^{\mathrm{a}}$ & 201 & $4.9^{\mathrm{a}}$ & 134 & $0.5^{\mathrm{a}}$ & 1.4 & $4.5^{\mathrm{a}}$ & 115 & $0.8^{\mathrm{a}}$ & 9.0 \\
\hline & & $\mathrm{P}(\mathrm{F})$ & $<0.001$ & - & 0.322 & - & 0.418 & - & 0.211 & - & 0.022 & - & 0.642 & - \\
\hline & Sowing date $\times$ Hybrid & $P(F)$ & 0.364 & - & 0.060 & - & 0.340 & - & 0.802 & - & 0.334 & - & 0.316 & - \\
\hline \multirow[t]{8}{*}{2015} & \multirow[t]{3}{*}{ Sowing date } & Early & $2.5^{b}$ & 83 & $4.5^{\mathrm{b}}$ & 120 & $2.0^{\mathrm{b}}$ & 13 & $0.1^{\mathrm{a}}$ & 0.1 & $2.7^{\mathrm{a}}$ & 22 & $1.4^{\mathrm{a}}$ & 14.4 \\
\hline & & Late & $6.0^{\mathrm{a}}$ & 742 & $5.7^{\mathrm{a}}$ & 400 & $4.6^{\mathrm{a}}$ & 152 & $<\mathrm{LOQ}^{\mathrm{a}}$ & $<\mathrm{LOQ}$ & $3.1^{\mathrm{a}}$ & 82 & $0.3^{\mathrm{a}}$ & 1.0 \\
\hline & & $P(F)$ & 0.002 & - & 0.004 & - & $<0.001$ & - & 0.337 & - & 0.473 & - & 0.122 & - \\
\hline & \multirow[t]{4}{*}{ Hybrid } & P1208 & $3.1^{\mathrm{a}}$ & 77 & $4.4^{b}$ & 108 & $2.8^{\mathrm{a}}$ & 29 & $0.1^{\mathrm{a}}$ & 0.2 & $2.4^{\mathrm{a}}$ & 20 & $1.2^{\mathrm{a}}$ & 14.8 \\
\hline & & DKC6815 & $5.6^{\mathrm{a}}$ & 822 & $5.2^{\mathrm{ab}}$ & 287 & $3.1^{\mathrm{a}}$ & 78 & $<\mathrm{LOQ}^{\mathrm{a}}$ & $<\mathrm{LOQ}$ & $3.3^{\mathrm{a}}$ & 116 & $1.0^{\mathrm{a}}$ & 7.9 \\
\hline & & PR32B10 & $4.0^{\mathrm{a}}$ & 339 & $5.6^{\mathrm{a}}$ & 386 & $4.0^{\mathrm{a}}$ & 140 & $<\mathrm{LOQ}^{\mathrm{a}}$ & $<\mathrm{LOQ}$ & $3.0^{\mathrm{a}}$ & 20 & $0.2^{\mathrm{a}}$ & 0.4 \\
\hline & & $P(F)$ & 0.115 & - & 0.050 & - & 0.140 & - & 0.397 & - & 0.458 & - & 0.451 & - \\
\hline & Sowing date $\times$ Hybrid & $\mathrm{P}(\mathrm{F})$ & 0.797 & - & 0.993 & - & 0.282 & - & 0.397 & - & 0.131 & - & 0.395 & - \\
\hline
\end{tabular}

AUR, aurofusarin ( $\mathrm{LOQ}=$ limit of quantification $=2.4 \mu \mathrm{g} \mathrm{kg}{ }^{-1}$ ); MON, moniliformin ( $\mathrm{LOQ}=1.6 \mu \mathrm{g} \mathrm{kg}^{-1}$ ); BEA, beauvericin ( $\left.\mathrm{LOQ}=0.008 \mu \mathrm{kg}^{-1}\right)$; $\mathrm{ENNs}$, sum of enniatins B, $\mathrm{B}_{1}, \mathrm{~B}_{2}$ ( $\mathrm{LOQ}=0.04 \mu \mathrm{g} \mathrm{kg}{ }^{-1}$ ); $\mathrm{EQU}$, equisetin $\left(\mathrm{LOQ}=0.24 \mu \mathrm{g} \mathrm{kg}^{-1}\right) ; \mathrm{T}-2$ toxin $\left(\mathrm{LOQ}=0.8 \mu \mathrm{g} \mathrm{kg}{ }^{-1}\right)$ and HT-2 toxin $\left(\mathrm{LOQ}=3.2 \mu \mathrm{g} \mathrm{kg}^{-1}\right)$. The mycotoxin contamination means reported are transformed [T; $\left.\mathrm{y}^{\prime}=\ln (\mathrm{x}+1)\right]$ and non-transformed $(\mathrm{N})$ values. ${ }^{\mathrm{a}, \mathrm{b}} \mathrm{Means}$ followed by different letters are significantly different (the level of significance is shown in the table). The sowing date values are based on 9 replicates ( 3 hybrids $\times 3$ replications), while the hybrid values are based on 6 replicates ( 2 sowing dates $\times 3$ replications). 
their toxin contents produced by $F$. graminearum and F. culmorum (DON, DON-3-G, NIV, CULM, ZEA, BUT) and to their AUR (loadings $>|0.77|$ ). On the other hand, the second component differentiated the samples according to their toxin contents produced by $F$. verticillioides and $F$. proliferatum (FBs, FAs, Fusarin C, FA, BIK and FUS). The contaminations of MON and BEA, which are mainly produced by $F$. subglutinans (section Liseola) and F. avenaceum (section Roseum), were found to be associated with FBs. When the production situations resulting from the combination of growing seasons, sowing time and hybrid were considered, five groups were identified. Group A clustered samples with an overall low content of all the mycotoxins considered in the PCA. On the contrary, the B and C group samples showed higher FB and FBassociated mycotoxin contents. These two groups only consisted of samples from both growing seasons characterised by a late sowing time. Moreover, the group $\mathrm{C}$ samples, which were characterised by the highest FB contamination, only referred to the full season maturity hybrids matured in the warmer and drier growing season (2015). The samples characterised by high contaminations of DON and DON-associated mycotoxins are clustered in groups D and E. All these samples refer to the 2014 growing season, which was characterised by more favourable environmental conditions to $F$. graminearum and F. culmorum infection. These two groups differed according to the hybrids that were clustered. In fact, the samples characterised by the highest DON and DON-associated metabolite contamination (group E) only came from the DKC6815 hybrid, which resulted more prone to $F$. graminearum and F. culmorum infection for both sowing times.

\section{Discussion}

The collected data indicate that the most prevalent mycotoxins and fungal metabolites in irrigated maize cultivated in temperate areas can be grouped into two main classes, depending on the environmental conditions that occur during cultivation. The main environmental conditions which influence the infection and the development of different fungal species are determined by the combination of the sowing date, the susceptibility and maturity length of the cultivated maize hybrid as well as the meteorological trends from flowering to the end of ripening of the maize kernel.

The first group of mycotoxins and fungal metabolites refers to fumonisins (FBs and FAs) and fumonisin-associated mycotoxins, such as Fusarin C, FA, BIK and FUS, all of which are produced mainly by $F$. verticillioides and $F$. proliferatum. As regards the occurrence of this class of compounds, FBs were detected in both growing seasons, and as also reported in several previous scientific works, FBs are by far the most abundant mycotoxins in Northern Italian maize (Pietri et al., 2004; Blandino et al., 2015). To the best of the authors' knowledge, this is the first work that has reported the co-occurrence of FBs and FAs, which are the N-acetyl analogs of FBs, in maize grain samples.

Moreover, the present study reports data on the natural content of Fusarin C, whose presence has only been reported in South Africa in selected maize kernels (Gelderblom et al., 1984) and in Germany in whole maize and feed samples, but on those occasions the levels of contamination were at least 10 times lower (Kleigrewe et al., 2011).

Although the relative concentrations of these metabolites could change according to the growing season, they all showed a similar response following the application of the compared cropping systems. In particular, the late sowing time was found to significantly increase the concentration of all these compounds in both growing seasons. In fact, the delay of sowing, and consequently of kernel ripening, may result in more favourable conditions for the development of Fusarium species in the final part of ripening, and may prolong the kernel dry down (Doohan et al., 2003; Nielsen et al., 2002). Moreover, the late sowing time resulted in a higher level of ECB damage of the ears (Blandino et al., 2008), and the damage of this insect is not only clearly correlated to fumonisin occurrence (Munkvold, 2003; Blandino et al., 2009a), but also to the presence of BIK, FUS, FA, MON and BEA (Blandino et al., 2015). Late sowing shifts the ear development phase of the crop to a period with greater insect activities, and this produces more kernel injuries due to ECB larvae, which in turn favours a higher $F$. verticillioides and F. proliferatum infection (Blandino et al., 2009b). Although an insecticide was applied in all the compared situations to minimise insect damage, the later sowing time in 2015 resulted in a higher level of ECB larva injury than the early one.

The increase in the content of fumonisins and other metabolites produced by $F$. verticillioides and $F$. proliferatum due to the delay of sowing was more pronounced in the 2015 growing season, which was characterised by less favourable environmental conditions for infection by other Fusarium species, such as F. graminearum, F. culmorum and $F$. avenaceum. This finding confirms the results on fumonisins reported by Parson and Munkvold (2012) in the U.S.A., which pointed out a higher risk for late sowings in years with dryer and warmer conditions after pollination, in which the competition between $F$. verticillioides and $F$. proliferatum and other Fusaria species is lower. Moreover, the risk of contamination by fumonisins and fumonisin-associated metabolites after a late sowing is higher for full season maturity hybrids than for earlier hybrids. In these production situations, the combination of late sowing time and full season maturity hybrids creates conditions in which the exposure to the ECB activity is more critical, and the development of the fungal species responsible for contamination is increased. In previous research, in which the early sowing time was employed, the contamination of fumonisins did not seem to be clearly influenced by the hybrid maturity length (Blandino and Reyneri, 2008; Camardo Leggieri et al., 2015), but did seem to be influenced by the hardness or the chemical composition of the grain, which was found to influence fungal infection and development. Conversely, Pietri et al. (2012) reported a higher FB contamination in medium-early and full season maturity hybrids (FAO maturity classes 500 and 600) than in early maturity hybrids (FAO maturity class 300 ), none of which have been considered in the present study.

The second class of fungal metabolites refers to deoxynivalenol and its related metabolites. The content of acetylated forms of deoxynivalenol, DON-3-G, and of all the other fungal metabolites produced by $F$. gramineaurum and F. culmorum (CULM, NIV, ZEA, BUT), were found to be closely correlated to the deoxynivalenol content, as already reported for wheat (Blandino et al., 2017). Moreover, AUR was also found to be correlated to DON contamination, and to follow the same trend of contamination. The high occurrence of these metabolites in maize is generally associated with wet and cool growing seasons (Doohan et al., 2003). An increase in deoxynivalenol content was previously reported after the application of a late sowing date (Blandino et al., 2009b) or after delaying the harvest date (Lauren et al., 2007), as was also observed for the 2015 conditions. Furthermore, the data of the present study clearly underline that the contamination of these metabolites depends more on the conditions that occur during maize flowering than those that occur during ripening. The meteorological conditions in July 2014 made the early-planted maize 
more prone to fungal producer infection than the maize planted at the late sowing dates, which were characterised by a delay of flowering at the beginning of August. Moreover, DON, DON-3-G, ZEA, CULM, BUT and AUR were detected in 2014 at much higher levels of contamination than those reported in another work on a three-year study in the same growing area (Blandino et al., 2015).

The importance of flowering infection on the contamination of DON and DON-associated mycotoxins can be confirmed by considering the clear susceptibility observed in the DKC6815 cultivar, compared to the other hybrids with similar (PR32B10) or different (P1208) precocity. While the resistance sources to $F$. verticillioides and fumonisin accumulations are polygenic and more difficult to incorporate in hybrids (Clements et al., 2003), the genetic control of $F$. graminearum in maize hybrids is regulated by just a few genes and is closely linked to silk infection (Reid et al., 1994; Chungu et al., 1996).

The MON and BEA levels seemed to be connected to those of the fumonisins, as already reported by Blandino et al. (2015) in a work that considered maize ears with variable injuries caused by insects. Furthermore, the contamination by these metabolites is influenced less by the sowing date and the type of hybrid than FBs. This might be due to the fact that these compounds can be synthesised by several fungal species characterised by different ecologies.

Although the study compared production situations with clearly different environmental conditions, other metabolites produced by Fusarium species, such as ENNs, EQU, T-2 and HT-2 toxins and Alternaria toxins (AOH, AME, TENT), were always found in traces or at low concentrations in the maize, compared to wheat cultivated in the same growing areas (Blandino et al., 2017). Thus, the occurrence of these metabolites seems to be influenced less by the compared agronomic practices. To the best of the authors' knowledge, this is the first work that has reported, although only in traces, the presence of ENNs and Alternaria toxins in maize grains from South European fields.

T-2 and HT-2 toxins were found more frequently in samples taken from early-sown plots, although no differences were observed among the considered hybrids. The higher T-2 and HT-2 toxin contents could be an indirect consequence of a change in the relative competition capacity among the fungal species. The application of an early sowing date and of an insecticide treatment against ECB is known to reduce FB-producer infection, and consequently an increase in the infection by less predominant fungal species may be possible.

No metabolites produced by Penicillium or by other fungal genera were detected in any of the compared production situations. However, it has been well documented that the contamination of maize grain by aflatoxins could occur in different growing areas and seasons from those considered in this study. Again in this case, the sowing date may have had an important effect on aflatoxin contamination; in fact, as reported in previous studies, the application of a late sowing may increase aflatoxin contamination (Wiatrak et al., 2005; Camardo Leggieri et al., 2015).

\section{Conclusions}

The results of these experiments, obtained under naturallyinfected field conditions, underline the key role of agronomic strategies in influencing the contamination by mycotoxins produced by different Fusarium species in maize. The choice of the sowing date and the use of certain hybrids could shift the most critical growth stages of maize from flowering to the end of ripening, in weeks characterised by different environmental factors, and this could result in a variable selection of the fungal species that can infect and develop on maize ears. The effect of these crop techniques on the overall control of mycotoxins clearly interacts with the meteorological trends of the growing seasons, and could result in changeable behaviour of all the different compounds. These results, which need to be confirmed in other environments, lead to an improvement in knowledge on the control of these contaminants in maize cultivations, which could help in the design of integrated management strategies that are able to minimise the overall risk of mycotoxin contamination in this crop in different growing areas.

\section{References}

Binder EM, Tan LM, Chin LJ, Handl J, Richard J, 2007. Worldwide occurrence of mycotoxins in commodities, feeds and feeds ingredients. Anim. Feed Sci. Technol. 137:265-82.

Blandino M, Reyneri A, 2008. Effect of maize hybrid maturity and grain hardness on fumonisin and zearalenone contamination. Ital. J. Agron. 2:107-17.

Blandino M, Reyneri A, Colombari G, Pietri A, 2009a. Comparison of integrated field programmes for the reduction of fumonisin contamination in maize kernels. Field Crop. Res. 111:284-9.

Blandino M, Reyneri A, Vanara F, 2009b. Effect of sowing time on toxigenic fungal infection and mycotoxin contamination of maize kernels. J. Phytopathol. 157:7-14.

Blandino M, Reyneri A, Vanara F, Pascale M, Haidukowski M, Saporiti M, 2008. Effect of sowing date and insecticide application against European corn borer (Lepidoptera: Crambidae) on fumonisin contamination in maize kernels. Crop Prot. 27:1432-6

Blandino M, Reyneri A, Vanara F, Tamietti G, Pietri, A, 2009c. Influence of agricultural practices on Fusarium infection, fumonisin and deoxynivalenol contamination of maize kernels. World Mycotox. J. 2:409-18.

Blandino M, Scarpino V, Sulyok M, Krska R, Reyneri A, 2017. Effect of agronomic programmes with different susceptibility to deoxynivalenol risk on emerging contamination in winter wheat. Eur. J. Agron. 85:12-24.

Blandino M, Scarpino V, Vanara F, Sulyok M, Krska R, Reyneri A, 2015. The role of the European Corn Borer (Ostrinia Nubilalis) on contamination of maize with 13 Fusarium mycotoxins. Food Addit. Contam. A 32:533-43.

Camardo Leggieri M, Bertuzzi T, Pietri A, Battilani P, 2015. Mycotoxin occurence in maize produced in Northern Italy over the years 2009-2011: focus on the role of crop related factors. Phytopathol. Medit. 54:212-21.

Chungu C, Mather DE, Reid LM, Hamilton RI, 1996. Comparison of techniques for inoculating silk, kernel and cob tissues with Fusarium graminearum. Plant Dis. 80:81-4.

Clements MJ, Kleinschmidt CE, Maragos CM, Pataky JK, White DG, 2003. Evaluation of inoculation techniques for Fusarium ear rot and fumonisin contamination of corn. Plant Dis. $87: 147-53$

Doohan FM, Brennan J, Cooke BM, 2003. Influence of climatic factors on Fusarium species pathogenic to cereals. Eur. J. Plant Pathol. 109:755-68.

EFSA, 2010. Request for a scientific opinion on the risks for public 
health related to the presence of moniliformin in feed and food. Mandate M-2010-0312. European Food Safety Authority, Parma, Italy.

EFSA, 2014. Scientific opinion on the risks to human and animal health related to the presence of beauvericin and enniatins in food and feed. EFSA J 12:3802.

European Commission, 2006a. Commission regulation No. 1881/2006, of 10 December 2006 setting maximum levels for certain contaminants in food stuff. In: Official Journal, L 364, pp. $5-24$.

European Commission, 2006b. Commission recommendation 576/2006 of 17 August 2006 on the presence of deoxynivalenol, zearalenone, ochratoxin A, T-2 and HT-2 and fumonisins in products intended for animal feeding. In: Official Journal, L 229, pp. 7-9.

European Commission, 2007. Commission regulation No. 1126/2007 of 28 September 2007 amending Regulation (EC) No 1881/2006 setting maximum levels for certain contaminants in foodstuffs as regards Fusarium toxins in maize and maize products. In: Official Journal, L 255, pp. 14-7.

European Commission, 2011. Commission regulation No. 574/2011 of 16 June 2011 amending Annex I to Directive 2002/32/EC. In: Official Journal, L 159, pp. 7-24.

Gelderblom WCA, Thiel PG, Marasas WFO, Van der Merwe KJ, 1984. Natural occurrence of fusarin C, a mutagen produced by Fusarium moniliforme, in corn. J. Agric. Food Chem. 32:1064-7.

Kleigrewe K, Söhnel AC, Humpf HU, 2011. A new high-performance liquid chromatography_tandem mass spectrometry method based on dispersive solid phase extraction for the determination of the mycotoxin fusarin $\mathrm{C}$ in corn ears and processed corn samples. J. Agric. Food Chem. 59:10470-6.

Kovalsky P, Kos G, Nährer K, Schwab C, Jenkins T, Schatzmayr G, Sulyok M, Krska R, 2016. Co-occurrence of regulated, masked and emerging mycotoxins and secondary metabolites in finished feed and maize - an extensive survey. Toxins 8:363.

Lancashire PD, Bleiholder H, Longelüddcke P, Stauss R, Van Den Boom T, Weber E, Witzenberger A, 1991. An uniform decimal code for growth stages of crops and weeds. Ann. Appl. Biol. 119:561-601.

Lauren DR, Smith WA, Di Menna ME, 2007. Influence of harvest date and hybrid on the mycotoxin content of maize (Zea mays) grain grown in New Zealand. N. Z. J. Crop Hortic. Sci. 35:33140.

Lee HJ, Ryu D, 2017. Worldwide occurrence of mycotoxins in cereals and cereal-derived food products: public health perspectives of their co-occurrence. J. Agric. Food Chem. 65:7034-51.
Malachova A, Sulyok M, Beltran E, Berthiller F, Krska R, 2014. Optimization and validation of a quantitative liquid chromatography - tandem mass spectrometric method covering 295 bacterial and fungal metabolites including all relevant mycotoxins in four model food matrices. J. Chromatogr. A 1362:145-56.

Munkvold GP, 2003. Cultural and genetic approaches to managing mycotoxins in maize. Annu. Rev. Phytopathol. 41:99-116.

Nielsen RL, Thomison PR, Brown GA, Halter AL, Wells J, Wuethrich KL, 2002. Delayed planting effects on flowering and grain maturation of dent corn. Agron. J. 94:549-58.

Parson, MW, Munkvold GP, 2012. Effects of planting date and environmental factors on Fusarium ear rot symptoms and fumonisin $\mathrm{B}_{1}$ accumulation in maize grown in six North American locations. Plant Pathol. 61:1130-42.

Pietri A, Battilani P, Gualla A, Bertuzzi T, 2012. Mycotoxin levels in maize produced in northern Italy in 2008 as influences by growing location and FAO class of hybrid. World Mycotoxin J. 5:409-18.

Pietri A, Bertuzzi T, Pallaroni L, Piva G, 2004. Occurrence of mycotoxins and ergosterol in maize harvested over 5 years in Northern Italy. Food Addit. Contam. 21:479-87.

Pinotti L, Dell'Orto V, 2011. Feed safety in the feed supply chain. Biotechnol. Agron. Soc. 15:9-14.

Pinotti L, Ottoboni M, Giromini C, Dell'Orto V, Cheli F, 2016. Mycotoxin contamination in the EU feed supply chain: a focus on cereal byproducts. Toxins 8:45.

Reid LM, Mather DE, Bolton AT, Hamilton RI, 1994. Evidence for a gene for silk resistance to Fusarium graminearum Schw. ear rot of maize. J. Hered. 85:118-21.

Streit E, Schwab C, Sulyok M, Naehrer K, Krska R, Schatzmayr G, 2013. Multi-mycotoxin screening reveals the occurrence of 139 different secondary metabolites in feed and feed ingredients. Toxins 5:504-23.

Sulyok M, Berthiller F, Krska R, Schuhmacher R, 2006. Development and validation of a liquid chromatography/tandem mass spectrometric method for the determination of 39 mycotoxins in wheat and maize. Rapid Commun. Mass Spectrom. 20:2649-59.

Wiatrak PJ, Wright DL, Marois JJ, Wilson D, 2005. Influence of planting date on aflatoxin accumulation in Bt, non-Bt, and Tropical non-Bt Hybrids. Agron. J. 97:440-5.

Wild CP, Gong YY, 2010. Mycotoxins and human disease: a largely ignored global health issue. Carcinogenesis 167:101-34.

Wu F, 2007. Measuring the economic impacts of Fusarium toxins in animal feed. Anim. Feed Sci. Technol. 137:363-74. 